\title{
ANALISIS TEKNIS DAN FINANSIAL USAHA PENANGKAPAN JARING RAMPUS (GILL NET) DI PANGKALAN PENDARATAN IKAN (PPI) CITUIS, KABUPATEN TANGERANG
}

\section{Technical and Financial Analysis of Gill Net at Cituis Fishing Port, Tangerang Regency}

\author{
*Lusy Maulia Juliani, Abdul Kohar Mudzakir dan Dian Wijayanto \\ Departemen Perikanan, Universitas Diponegoro \\ JI. Prof. Soedarto, SH Tembalang, Semarang, Jawa Tengah, Indonesia \\ Diterima tanggal: 25 Maret 2019 Diterima setelah perbaikan: 5 Mei 2019 \\ Disetujui terbit: 24 Juni 2019
}

\begin{abstract}
ABSTRAK
Kabupaten Tangerang memiliki potensi perikanan laut yang melimpah. Alat tangkap yang banyak digunakan di Kabupaten Tangerang adalah cantrang, arad, payang, pancing ulur, bubu dan gill net. Jaring rampus merupakan alat tangkap jaring insang hanyut yang biasa digunakan nelayan untuk menangkap ikan-ikan pelagis kecil seperti ikan Kembung (Rastrelliger spp) dan ikan Layur (Trichiurus lepturus). Penelitian ini bertujuan untuk mengetahui teknis penangkapan jaring rampus dan mengkaji kelayakan usaha penangkapan jaring rampus di PPI Cituis. Penelitian ini dilakukan pada Bulan Desember 2018 Januari 2019. Metode penelitian ini adalah survei. Metode analisis aspek teknis yang digunakan yaitu hanging ratio, shortening, tinggi jaring dan luas jaring dari alat tangkap jaring rampus. Metode analisis finansial usaha yang digunakan yaitu NPV, IRR, R/C ratio, ROI, BEP, PP dan Analisis Sensitivitas. Hasil penelitian menunjukan bahwa kapal jaring rampus berukuran 5-6 GT dan memiliki mesin penggerak berkekuatan 16-30 PK. Hasil dari analisis teknis alat tangkap jaring rampus yang diperoleh nilai hanging ratio sebesar 0,6; shortening sebesar 0,4; tinggi jaring sebesar 3,672 m dan luas jaring sebesar 144,7 $\mathrm{m}^{2}$ dalam satu helai. Hasil analisis kelayakan usaha yang diperoleh nilai R/C ratio sebesar 1,17; BEP harga sebesar Rp68.208,-; BEP produksi sebesar 2.266 kg; ROI sebesar 17\%; NPV sebesar Rp196.664.224,-; IRR sebesar 64,93\%; PP sebesar 3,625 tahun dan Analisis sensitifitas < 1. Kesimpulannya bahwa usaha penangkapan Jaring rampus di pangkalan pendaratan ikan (PPI) Cituis, Kabupaten Tangerang layak untuk diusahakan atau dilanjutkan.
\end{abstract}

Kata Kunci: PPI Cituis; jaring rampus; aspek teknis; analisis finansial

\begin{abstract}
Tangerang Regency has abundant fishery resource potential. The fishing gears in Tangerang Regency are danish seine, mini trawl, line, trap and gill net. Fishermen are using gill net to that is widely used catch small pelagic fish such as Mackerel and Fish Belt. This research aims to analyse the technical operation and business feasibility of gill net at Cituis fishing port. The survey was conducted in December 2018 to January 2019. The research method that has been used is the survey. Hanging ratio, shortening, net height and net broad were used to analyse the technical aspect of gill net. Meanwile, NPV, IRR, R/C ratio, $R O I, B E P$, Payback Periods and sensitivity analysis were used to analyse the financial feasibility of gill net business. The results showed that gill net fishing boats are $<5$ GT and have 16-30 PK propulsion engines. The research finds that hanging ratio of gill net in Cituis fishing port is 0.6; shortening of 0.4; net height of $3.672 \mathrm{~m}$ and net broad of $144.7 \mathrm{~m}^{2}$ in one peace. Financial analysis resulted in $R / C$ ratio 1.17; BEP price Rp68,208,-; BEP production 2,266 kg; ROI 17\%; NPV Rp196,664,224,-; IRR 64.93\%; $P P 3.625$ years and sensitivity analysis $<1$. Therefore, this study suggests that gill net fishery at Cituis fishing port is reasonable to be developed.
\end{abstract}

Keywords: PPI Cituis; gill net; technical aspects; financial analysis 


\section{PENDAHULUAN}

PPI Cituis merupakan salah satu di antara tujuh PPI di Kabupaten Tangerang yang paling aktif melakukan pelelangan ikan. PPI Cituis juga terkenal sebagai tempat penjualan ikan laut segar dan ikan air tawar segar di Tangerang. Menurut Dinas Perikanan Kabupaten Tangerang menyatakan bahwa pelelangan ikan di PPI Cituis dilakukan hamper setiap hari (Damayanti, Bambang \& Sardiyatmo, 2014). Jenis alat penangkapan ikan yang digunakan di PPI Cituis antara lain cantrang, gill net, pancing ulur, payang dan bubu. Jenis alat penangkapan ikan yang dominan di PPI Cituis adalah gill net, bubu dan pancing. Alat tangkap yang menjadi fokus penelitian adalah jaring rampus (gill net).

Alat tangkap jaring rampus yang digunakan untuk nelayan di sekitar PPI Cituis memiliki perkembangan yang baik setiap tahunnya, sehingga penting untuk mengetahui aspek teknis dari alat tangkap jaring rampus sebagai acuan untuk mengembangkan usaha penangkapan dari jaring rampus. Usaha penangkapan jaring rampus bukan teknologi yang baru bagi para nelayan. Nelayan menggunakan alat tangkap jaring rampus karena bahan mudah diperoleh, mudah dioperasikan dan biaya pengoperasian alat terjangkau. Namun masih banyak nelayan Jaring Rampus di PPI Cituis yang tidak menghitung secara keseluruhan analisis usaha penangkapan secara ekonomi. Oleh karena itu perlu dilakukan penelitian mengenai teknis dan finansial usaha penangkapan jaring rampus di PPI Cituis, Kabupaten Tangerang.

Berdasarkan uraian di atas, maka penelitian ini dilaksanakan untuk menganalisis aspek teknis dan finansial pada usaha penangkapan jaring rampus. Aspek teknis meliputi spesifikasi kapal dan alat tangkap, daerah penangkapan, metode operasi serta hasil tangkapan sedangkan aspek finansial yaitu dengan menghitung kriteria Net Present Value (NPV), Internal Rate of Return (IRR), Revenue Cost Ratio (R/C Ratio), Break Even Point (BEP), Payback Periods (PP), Return on Investment (ROI) dan Analisis Sensitivitas.

Tujuan dari penelitian ini adalah (1) mengetahui teknis penangkapan jaring rampus; (2) mengkaji kelayakan usaha penangkapan jaring rampus di PPI Cituis, Kecamatan Pakuhaji, Kabupaten Tangerang. Survei lapangan telah dilaksanakan pada bulan Desember 2018 - Januari 2019 di PPI Citus Kecamatan Pakuhaji Kabupaten Tangerang Provinsi Banten.

Obyek yang digunakan pada penelitian ini adalah unit usaha penangkapan ikan dengan alat tangkap jaring rampus yang mendaratkan hasil tangkapannya di PPI Cituis Kabupaten Tangerang. Aspek yang diamati dalam penelitian ini adalah aspek teknis, aspek ekonomis dan analisa usaha dari penangkapan ikan menggunakan jaring rampus. Analisis yang digunakanan meliputi analisis deskriptif dan kuantititaf berdasar data primer dan sekunder yang diperoleh selama survei lapangan. Survei dilakukan untuk mengumpulkan data tentang usaha penangkapan yang menggunakan jaring rampus di PPI Cituis Kabupaten Tangerang. Metode deskriptif digunakan untuk mengumpulkan informasi mengenai aktivitas penangkapan mencangkup aspek teknis (konstruksi jaring rampus, metode pengoperasian, daerah penangkapan ikan dan kapal). Sedangkan metode kuantitatif digunakan dalam analisis finansial kapal menggunakan alat jaring rampus yang meliputi pendapatan,biaya, pendapatan, keuntungan, NPV, IRR, ROI, R/C Ratio dan PP dari usaha penangkapan jaring rampus.

Metode penentuan sampel yang digunakan merupakan purposive sampling. Purposive sampling adalah teknik penentuan sampel dengan pertimbangan tertentu. Metode ini digunakan karena keterbatasan waktu dan tenaga peneliti (Sugiyono, 2012 dalam Setiawati et al., 2015). Besarnya populasi dari unit usaha penangkapan jaring rampus di PPI Cituis sebanyak 100 unit, sehingga jumlah sampel yang akan diambil dari nelayan jaring rampus adalah sebanyak 12 orang. Menurut Suparmoko (2003), banyak sampel yang digunakan dalam penelitian dapat dihitung dengan rumus:

$$
\mathrm{n}=\frac{\mathrm{NZ}}{\mathrm{Nd}^{2} \mathrm{P}(1-\mathrm{P})}
$$

\section{Keterangan:}

$\mathrm{n}$ : Jumlah sampel penelitian

$\mathrm{N}$ : Jumlah populasi sampel

$\mathrm{d}$ : Kesalahan maksimum yang dapat diterima $(0,1)$

$Z$ : Variabel normal standar $(1,64)$

$P$ : Persentase variance ditetapkan $(0,05)$ 
Metode pengumpulan data dalam penelitian ini menggunakan metode survei, sedangkan teknik pengambilan data yang digunakan adalah observasi, studi dokumentasi, studi pustaka dan wawancara. Data primer yang digunakan dalam penelitian ini berupa tanya jawab langsung dengan pihak-pihak yang terkait. Data primer yang dibutuhkan antara lain:

1. Aspek teknis, meliputi desain dan kontruksi, metode pengoperasian, daerah penangkapan ikan, jumlah dan jenis hasil tangkapan, musim penangkapan dan kapal yang digunakan dalam penangkapan jaring rampus; dan

2. Aspek finansial, meliputi modal, biaya, pendapatan dan keuntungan.

Data sekunder yang diperoleh dari penelitian ini berupa data jumlah produksi ikan, jumlah kapal penangkap ikan, jumlah nelayan, jumlah alat tangkap dan kondisi perikanan di Kabupaten Tangerang.

Metode analisis data aspek teknis yang digunakan dalam penelitian ini menggunakan rumus hanging ratio, shortening, tinggi jaring dan luas jaring (Prado, 2012) sebagai berikut:

a. Hanging Ratio (E)

$$
\mathrm{E}=\frac{L}{L o}
$$

\section{b. Shortening (S)}

$$
\mathrm{S}=\frac{L-L o}{L} 100 \%
$$

c. Tinggi Jaring dan Luas Jaring

$$
\begin{gathered}
\text { Tinggi jaring }(\mathrm{m})=\text { tinggi teregang }(\mathrm{m}) \times \sqrt{1-E^{2}} \\
\mathrm{~S}=\mathrm{E} \times{\sqrt{1-E^{2}} \times \mathrm{L} \times \mathrm{H} \times \mathrm{a}^{2}}^{2}
\end{gathered}
$$

Keterangan:

$$
\begin{aligned}
\mathrm{E}= & \text { Hanging Ratio } \\
\mathrm{S}= & \text { Shortening } \\
\mathrm{L}= & \text { Panjang tali ris tempat jaring terpasang } \\
& \quad \text { (panjang jaring jadi) } \\
\mathrm{LO}= & \text { Panjang jaring dalam keadaan stretch } \\
& \text { (terenggang penuh) } \\
\mathrm{S}= & \text { Luas permukaan Jaring }\left(\mathrm{m}^{2}\right) \\
\mathrm{E}= & \text { Hanging ratio (mendatar) } \\
\mathrm{L}= & \text { Jumlah mata jaring (mendatar) } \\
\mathrm{H}= & \text { Jumlah mata jaring tegak } \\
\mathrm{a}= & \text { Ukuran mata jaring teregang }\left(\mathrm{m}^{2}\right)
\end{aligned}
$$

Metode analisis finansial dalam penelitian ini menggunakan variabel $R O I, B E P, R / C$ ratio, NPV, IRR, Payback Periods dan Analisis Sensitivitas. Rumus ROI, BEP, R/C ratio, NPV, IRR, Payback Periods dan Analisis Sensitifitas (Yunita, 2017) (Fitria, Affandi \& Nugraha, 2013) (Ambarita, Bathara, Yulinda, 2015) (Astanu, Ismono, \& Rosanti, 2013) (Brigham \& Houston, 2006) sebagai berikut:

a. Return on Investment (ROI)

$$
\mathrm{ROI}=\frac{\text { Keuntungan }}{\text { Total Biaya }} \times 100 \%
$$

\section{b. Break Even Point (BEP)}

$$
\begin{aligned}
& \text { BEP Produksi }(\mathrm{Kg})=\frac{\text { Total Biaya }(\mathrm{Rp})}{\text { Harga Jual }(\mathrm{Rp})} \\
& \text { BEP Harga }(R p)=\frac{\text { Total Biaya }(R p)}{\text { Jumlah Produksi }(R p)}
\end{aligned}
$$

c. Evenue Cost Ratio (R/C Ratio)

$$
\mathrm{R} / \mathrm{C}=\frac{\text { Total Pendapatan }(\mathrm{Rp})}{\text { Total Biaya }(\mathrm{Rp})}
$$

\section{d. Net Present Value (NPV)}

$$
\mathrm{NPV}=\sum_{\mathrm{t}=1}^{\mathrm{n}} \frac{\mathrm{Bt}-\mathrm{Ct}}{(1+\mathrm{i})^{t}}
$$

e. Internal Rate Return (IRR)

$$
\mathrm{IRR}=\mathrm{i}+\frac{\mathrm{NPV}}{\mathrm{NPV} V_{1}-\mathrm{NPV}_{2}}\left(\mathrm{i}_{2}-\mathrm{i}_{1}\right)
$$

f. Payback Periods (PP)

$$
\mathrm{PP}=\frac{\mathrm{n}+(\mathrm{a}+\mathrm{b}) \times 1}{(\mathrm{c}-\mathrm{b})}
$$

g. Analisis Sensitivitas

$$
S=\frac{\left[\frac{\mathrm{X} 1-\mathrm{X}_{0}}{\mathrm{X}}\right] \times 100 \%}{\left[\frac{\mathrm{Y} 1-\mathrm{Y}_{0}}{\mathrm{Y}}\right] \times 100 \%}
$$

Keterangan:

$$
\begin{array}{ll}
\mathrm{NPV} & =\text { Net Present Value } \\
\mathrm{t} & =\text { Waktu } \\
\mathrm{Bt} & =\text { Benefit (manfaat) } \\
\mathrm{Ct} & =\text { Cost (biaya) } \\
\mathrm{i} & =\text { Tingkat bunga bank yang berlaku } \\
\mathrm{NPV}_{1}= & \text { NPV yang masih Positif } \\
\mathrm{NPV}_{2}= & \text { NPV yang Negatif } \\
\mathrm{n} & = \\
& \text { Tahun terakhir dimana arus kas masih } \\
\mathrm{a} & =\text { Jumlah dapat menutup investasi awal } \\
\mathrm{b} & =\text { Jumlah kumulatif arus kas pada tahun } \\
& \text { ke } \mathrm{n} \\
\mathrm{C} & =\text { Jumlah kumulatif arus kas pada tahun } \\
& \mathrm{n}+1 \\
\mathrm{~S} & =\text { Sensitivitas } \\
\mathrm{X}_{1} & =\text { NPV/IRR/R/C ratio setelah terjadi } \\
& \text { perubahan }
\end{array}
$$




$$
\begin{aligned}
\mathrm{X}_{0} \quad= & \text { NPV/IRR/R/C ratio sebelum terjadi } \\
& \text { perubahan } \\
\mathrm{X}_{\mathrm{N}} & \text { Rata-rata perubahan NPV/IRR/R/C ratio } \\
\mathrm{Y}_{1}= & \text { Harga jual/biaya produksi/produksi } \\
& \text { setelah terjadi perubahan } \\
\mathrm{Y}_{0} \quad & \text { Harga jual/biaya produksi/produksi } \\
& \text { sebelum terjadi perubahan } \\
\mathrm{Y} & \text { Rata-rata perubahan harga jual/biaya } \\
& \text { produksi/produksi }
\end{aligned}
$$

Kriteria Kelayakan:

- ROI > i (tingkat suku bunga yang belaku), maka usaha layak diusahakan;

- BEP Harga < Harga jual ikan, maka usaha layak untuk diusahakan;

- R/C Ratio > 1, maka usaha mengalami keuntungan atau layak untuk diusahakan;

- NPV > 0, maka kegiatan usaha layak untuk diusahakan;

- IRR > discount rate (tingkat bunga) maka kegiatan usaha layak untuk diusahakan; dan

- Laju kepekaan <1, maka usaha tidak sensitif, artinya layak untuk diusahakan.

\section{KEADAAN UMUM PERIKANAN KABUPATEN TANGERANG}

Kabupaten Tangerang terletak pada posisi strategis, secara astronomi terletak pada koordinat $106^{\circ} 20^{\prime}-106^{\circ} 43^{\prime}$ Bujur Timur dan 6 ${ }^{\circ} 00^{\prime}-6^{\circ} 00-6^{\circ} 20^{\prime}$ Lintang Selatan. Kabupaten Tangerang memiliki tujuh PPI yaitu, Ketapang, Benyawakan, Kronjo, Cituis, Karang Serang, Tanjung Pasir dan Dadap. PPI Cituis merupakan salah satu PPI sentra sebagai UPTD di Kabupaten Tangerang karena ramainya aktivitas pelelangan ikan dan aktifnya tingkat operasional di pelabuhan. Data perikanan Kabupaten Tangerang pada tahun 2013 sampai 2017 dapat dilihat pada Tabel 1.

Jumlah armada penangkapan di Kabupaten Tangerang mengalami kenaikan pada tahun 2013-2015 dan penurunan pada tahun 2015-2017. Jumlah kapal penangkap ikan di Kabupaten Tangerang periode tahun 2013-2017 setiap tahunnya berfluktuasi dengan pertumbuhan rata-rata sebesar $-4 \%$. Jumlah armada penangkapan <5 GT mengalami penurunan yang drastis pada tahun 2015, sedangkan armada penangkapan 5-10 GT dan 10-30 GT mengalami peningkatan jumlah yang drastis juga pada tahun 2015. Armada penangkapan di Kabupaten Tangerang didominasi oleh kapal yang berukuran di bawah 5 GT disebabkan karena kegiatan penangkapan di Kabupaten Tangerang didominasi oleh alat tangkap seperti Bubu, Pancing dan Jaring Insang.

Jumlah nelayan di Kabupaten Tangerang dari tahun 2013 sampai dengan tahun 2017 memiliki jumlah yang fluktuatif dikarnakan mengalami penurunan atau peningkatan jumlah nelayan. Jumlah nelayan periode tahun 2013-2017 mengalami pertumbuhan rata-rata setiap tahunnya sebesar -1\%. Tahun 2013 ke tahun 2014 jumlah nelayan di Kabupaten Tangerang meningkat dari 10.000 orang menjadi 11.315 orang dan mengalami penurunan pada tahun 2015-2017 dari 11.315 orang menjadi 9.493 orang.

Tabel 1. Jumlah Armada Penangkapan di Kabupaten Tangerang Tahun 2013-2017.

\begin{tabular}{crrrrr}
\hline \multirow{2}{*}{ Ukuran Kapal (GT) } & \multicolumn{5}{c}{ Kapal (unit) } \\
\cline { 2 - 6 } & \multicolumn{1}{c}{$\mathbf{2 0 1 3}$} & $\mathbf{2 0 1 4}$ & $\mathbf{2 0 1 5}$ & $\mathbf{2 0 1 6}$ & $\mathbf{2 0 1 7}$ \\
\hline$<5$ & 2.346 & 2.445 & 258 & 2.364 & 1.718 \\
$5-10$ & 161 & 695 & 1.415 & 161 & 551 \\
$10-30$ & 146 & 16 & 1.790 & 146 & 58 \\
$>30$ & 35 & 4 & 4 & 35 & - \\
\hline Jumlah & $\mathbf{2 . 6 8 8}$ & $\mathbf{3 . 1 6 0}$ & $\mathbf{3 . 4 6 7}$ & $\mathbf{2 . 7 0 6}$ & $\mathbf{2 . 3 8 7}$ \\
\hline
\end{tabular}

Sumber: Dinas Perikanan dan Kelautan Kabupaten Tangerang, 2019.

Tabel 2. Jumlah Nelayan di Kabupaten Tangerang Tahun 2013-2017.

\begin{tabular}{lrrrrr}
\hline \multirow{2}{*}{ Nelayan } & \multicolumn{5}{c}{ Nelayan (orang) } \\
\cline { 2 - 6 } & $\mathbf{2 0 1 3}$ & $\mathbf{2 0 1 4}$ & $\mathbf{2 0 1 5}$ & $\mathbf{2 0 1 6}$ & $\mathbf{2 0 1 7}$ \\
\hline Juragan & 2.635 & 2.646 & 2.645 & 2.635 & 2.315 \\
Anak Buah Kapal (ABK) & 7.365 & 8.669 & 8.669 & 7.365 & 7.176 \\
\hline \multicolumn{1}{c}{ Jumlah } & $\mathbf{1 0 . 0 0 0}$ & $\mathbf{1 1 . 3 1 5}$ & $\mathbf{1 1 . 3 1 4}$ & $\mathbf{1 0 . 0 0 0}$ & $\mathbf{9 . 4 9 3}$ \\
\hline
\end{tabular}

Sumber: Dinas Perikanan dan Kelautan Kabupaten Tangerang, 2019. 
Tabel 3. Jumlah Alat Tangkap di Kabupaten Tangerang Tahun 2013-2017.

\begin{tabular}{lrrrrr} 
& \multicolumn{9}{c}{ Tahun } & Satuan: unit \\
\cline { 2 - 6 } \multicolumn{1}{c}{ Jenis Alat Tangkap } & $\mathbf{2 0 1 3}$ & $\mathbf{2 0 1 4}$ & $\mathbf{2 0 1 5}$ & $\mathbf{2 0 1 6}$ & $\mathbf{2 0 1 7}$ \\
& 139 & 820 & 820 & 139 & 544 \\
Payang & 297 & 442 & 442 & 297 & 247 \\
Dogol & 1.787 & 37.640 & 37.640 & 2.402 & 857 \\
Gill Net & 312 & - & - & 2 & 369 \\
Trammel Net & 121 & 63 & 63 & 121 & - \\
Bagan & 342 & - & - & - & - \\
Rawai Hanyut & 659 & 4.886 & 4.886 & 659 & 163 \\
Pancing & 32 & 1.558 & 1.558 & 32 & 15 \\
Sero & 2.522 & 44.700 & 44.700 & 2.533 & 275 \\
Bubu & 257 & 30 & 30 & 257 & 137 \\
Garok Kerang & - & - & - & 37 & 38 \\
Alat Lainnya & & - &
\end{tabular}

Sumber: Dinas Perikanan dan Kelautan Kabupaten Tangerang, 2019.

Jumlah alat tangkap yang ada di Kabupaten Tangerang pada tahun 2013 hingga tahun 2014 mengalami kenaikan hampir di setiap alat tangkap kecuali pada alat tangkap Bagan dan Garok Kerang. Sedangkan pada tahun 2015-2017 alat tangkap di Kabupaten Tangerang mengalami penurunan drastic kecuali pada alat tangkap Payang dan Trammel Net. Alat tangkap dominan yang ada di Kabupaten Tangerang adalah alat tangkap Jaring Rampus (Gill Net), Bubu dan Pancing. Alat tangkap tersebut dianggap paling menguntungkan dan ramah lingkungan bagi nelayan di Kabupaten Tangerang. Semua alat tangkap yang berada di Kabupaten Tangerang adalah alat tangkap yang beroperasi selama satu hari sampai tiga hari namun pengoperasiannya memiliki musim penangkapan yang berbeda-beda dapat dilihat pada Tabel 3 .

Kabupaten Tangerang memiliki potensi sumber daya ikan yang sangat besar pengaruhnya terhadap perkembangan potensi laut. Potensi laut di Kabupaten Tangerang sangat besar, sebab sebagian besar wilayah di Kabupaten ini terletak di pesisir laut. Produksi perikanan tangkap di Kabupaten Tangerang mengalami peningkatan dan penurunan setiap tahunnya. Jumlah produksi perikanan tangkap laut pada tahun 2013 hingga 2014 mengalami penurunan sebanyak 81,78 ton dan mengalami peningkatan pada tahun-tahun berikutnya. Jumlah produksi perikanan tangkap laut tertinggi pada tahun 2017 sebanyak 20.506,74 ton dan terendah pada tahun 2014 sebanyak $20.070,26$ ton. Hal ini disebabkan karena terjadi peningkatan dan penurunan jumlah alat tangkap di Kabupaten Tangerang selama 5 tahun terakhir (Gambar 1).

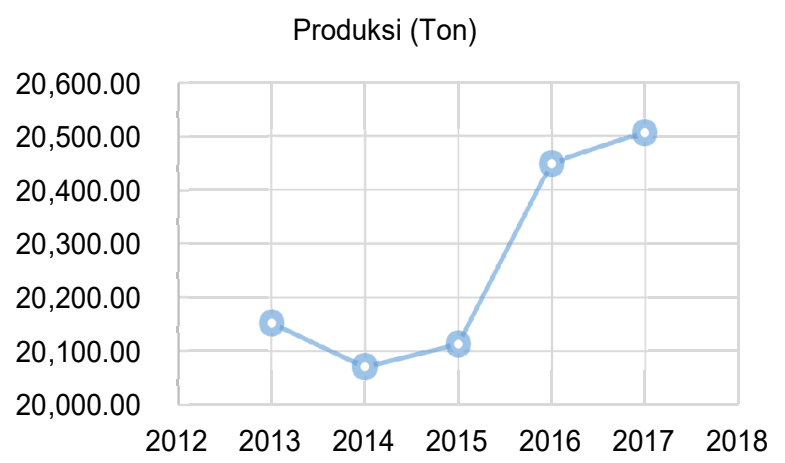

Gambar 1. Grafik Produksi Perikanan di Kabupaten Tangerang Tahun 2013-2017.

\section{Gambaran Umum Responden}

Nelayan jaring rampus di PPI Cituis sebanyak 240 orang terdiri dari 4 kelompok nelayan jaring rampus yang tiap kelompok terdiri dari 60 orang.

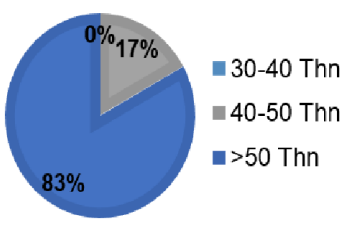

a. Umur

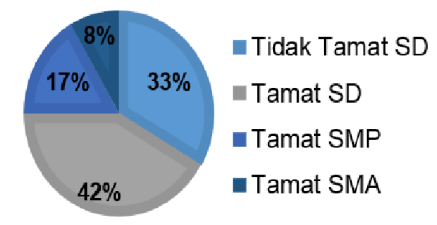

a. Pendidikan
Gambar 2. Klasifikasi Nelayan Jaring Rampus.

Presentase paling tinggi terdapat pada kisaran umur 40-50 tahun dengan presentase $83 \%$. Kisaran umur $40-50$ tahun dianggap masih dikategorikan produktif untuk tenaga kerja. Menurut Pangabean (2017), ada dua pengelompokan penduduk berkenaan dengan kaitan antara struktur umur dan kemampuan berproduksi secara ekonomi, yaitu: kelompok penduduk nonproduktif 
yaitu penduduk yang berumur $<15$ tahun dan $>64$ tahun serta kelompok usia produktif, yaitu penduduk yang berumur 15-64 tahun.

Tingkat pendidikan nelayan jaring rampus rata-rata yaitu tamat SD dengan presentase sebesar $42 \%$. Hal ini dikarenakan tidak adanya biaya dan kurangnya pengetahuan akan pentingnya pendidikan, sehingga nelayan kebanyakan lebih memfokuskan untuk mencari kerja.

Rata-rata nelayan jaring rampus berpengalaman kerja selama lebih dari 20 tahun. Pengalaman kerja ini dianggap cukup untuk menjalankan usaha penangkapan jaring rampus setiap tahunnya. Pengalaman kerja yang lama akan memberikan kesempatan kepada nelayan untuk dapat menyesuaikan diri dengan keadaan ekonominya dan lebih membantu dalam proses penangkapan karena sudah berpengalaman. Menurut Aprilyanti (2017), faktor-faktor yang mempengaruhi produktivitas seseorang dalam bekerjaadalah lamanya waktu bekerja. Pengalaman seseorang melaksanakan pekerjaan secara terus menerus mampu meningkatkan kedewasaan teknisnya.

\section{Aspek Teknis}

Kapal yang digunakan untuk mengoperasikan jaring rampus adalah kapal berukuran < 5 GT yang terbuat dari bahan kayu dengan ukuran panjang $12 \mathrm{~m}$, lebar $2,8 \mathrm{~m}$ dan tinggi $1,5 \mathrm{~m}$. Mesin yang digunakan pada kapal ini adalah mesin tempel berkekuatan 16-30 PK dan menggunakan solar sebagai bahan bakar.

Jaring rampus terdiri dari tali pelampung, tali pemberat, serampat atas, serampat bawah, tali ris atas, tali ris bawah, pemberat serta pelampung. Tali ris, tali pemberat, tali pelampung dan serampat terbuat dari bahan PE (polyethylene) dengan arah pilinan Z. Tali ris panjang $49,41 \mathrm{~m}$ diameter 6,8 $\mathrm{mm}$; tali pelampung panjang 49,41 $\mathrm{m}$ diameter 5,3 $\mathrm{mm}$; pelampung tanda bahan PVC dan pelampung biasa bahan PVC Y-3 (Plastik); bahan badan jaring adalah PA (polyamid) yang berwarna bening dengan mesh size $5,1 \mathrm{~cm}$ diameter $0,4 \mathrm{~mm}$; tali ris bawah panjang $59,26 \mathrm{~m}$ diameter $2,3 \mathrm{~mm}$; tali pemberat panjang $59,26 \mathrm{~m}$ diameter $3,1 \mathrm{~mm}$; pemberat yang digunakan terdapat 2 jenis terbuat dari batu dan timah; serampat berdiameter $0,5 \mathrm{~mm}$.

Kita temukan bahwa hanging ratio, shortening, tinggi dan luas jaring dapat mempengaruhi hasil tangkapan. Nilai hanging ratio 0,6 ; Shortening 0,4 ; sedangkan luas jaring rampus yang digunakan dalam 1 piece sebesar $144,7 \mathrm{~m}^{2}$. Hanging ratio pada alat tangkap gill net biasanya lebih dari 0,5 sedangkan hanging ratio yang didapatkan sebesar 0,6 yang berarti jaring rampus sudah efisien dalam penangkapan. Hal ini diperkuat oleh Prado (2012), yang menyatakan bahwa hanging ratio horizontal pada gill net umumnya sebesar 0,5 . Jika $\mathrm{E}<0,5$ jaring cenderung memuntal ikan. Jika $\mathrm{E}>0,5$ jaring cenderung menjerat ikan dan lebih selektif dibandingkan dengan jaring yang hanging ratio kurang dari 0,5.

Nelayan jaring rampus berangkat melaut dari fishing base sekitar pukul 03.00 WIB. Operasi penangkapan jaring rampus dilakukan selama 3 hari 2 malam per trip. Jarak yang diperlukan dari fishing base menuju fishing ground yaitu $\pm 25,6$ mil dengan waktu tempuh sekitar 5 jam. Daerah penangkapan nelayan jaring rampus yaitu di sekitar perairan Kepulauan Seribu yang termasuk kedalam WPP 712 (Laut Jawa). Target utama dari jaring rampus adalah ikan Kembung (rastrelliger spp) dan ikan Layur (trichiurus lepturus) sedangkan hasil tangkapan sampingan yaitu seperti ikan Pepetek (leiognathus equulus).

\section{Analisis Finansial}

Analisis Finansial dalam usaha perikanan menggunakan jaring rampus meliputi beberapa aspek yaitu modal usaha, pendapatan, biaya dan keuntungan. Suatu usaha dikatakan berhasil apabila secara ekonomis menguntungkan bagi pengusahanya. Dalam penyusunan cash flow dan analisis sensitivitas digunakan beberapa asumsi dan sekenario sensitivitas untuk membatasi permasalahan yang ada. Asumsi dan skenario sensitivitas yang digunakan dalam perkiraan cash flow dan analisis sensitivitas usaha penangkapan jaring rampus adalah sebagai berikut:

1. Umur proyek selama 10 tahun, dengan asumsi pada tahun ke-0 belum mendapatkan penerimaan;

2. Modal merupakan modal sendiri dan tidak ada kredit dari bank atau dengan yang lain;

3. Menggunakan discount factor $12 \%$ sesuai dengan dasar tingkat bunga bank BRI ratarata yang berlaku saat ini;

4. Upah Minimum Kerja (UMK) di Kabupaten Tangerang sebesar Rp 3.841.368,- per bulan berdasarkan Keputusan Gubernur Banten Nomor 561/KEP.318-Huk/2018; 
5. Penerimaan hanya didapatkan dari penjualan hasil tangkapan;

6. Untuk biaya penyusutan diasumsikan umur kapal 10 tahun, mesin 5 tahun, alat tangkap 2 tahun dan mesin bantu 5 tahun;

7. Pada tahun ke-1 sampai tahun ke10 penerimaan, modal dan biaya tetap diasumsikan mengalami kenaikan $5 \%$ di setiap tahunnya;

8. Skenario sensitivitas penurunan produksi ikan sebesar $15 \%$ didasarkan dari kondisi aktual yang pernah dialami nelayan;

9. Skenario sensitivitas kenaikan biaya operasional sebesar $5 \%$ didasarkan atas nilai inflasi rata-rata pada tahun 2013 sampai tahun 2018 Bank Indonesia (Tinjauan Kebijakan Moneter Bank Indinesia, 2019); dan

10. Skenario sensitivitas penurunan harga ikan sebesar $8 \%$ didasarkan pada kondisi aktual yang terjadi dilapangan yang diperoleh dari wawancara dengan nelayan.
Modal yang harus dikeluarkan untuk usaha penangkapan jaring rampus di PPI Cituis mencapi Rp112.412.500,-. Biaya tetap yang harus dikeluarkan per tahun yaitu sebesar Rp33.763.750,- sedangkan biaya tidak tetap sebesar Rp149.668.279,-. Jadi, biaya total yang diperoleh sebesar Rp183.432.029,- per tahun. Pendapatan nelayan jaring rampus sebesar Rp215.105.333,-. Sistem bagi hasil pada nelayan jaring rampus yaitu $40 \%$ untuk nelayan $A B K$ yaitu sebesar Rp43.624.702,- dengan ABK masingmasing sekitar Rp10.906.175.- per tahun dan Rp908.848,- per bulan < UMK. Sementara itu, juragan memperoleh $60 \%$ atau sebesar Rp65.437.008,- per tahun dan Rp5.453.084,per bulan > UMK. Keuntungan usaha jaring rampus setiap tahunnya sebesar Rp31.673.304,-Keuntungan tertinggi didapatkan saat musim puncak (Agustus - November), sedangkan terendah didapatkan saat musim paceklik (Desember - Maret).

Nilai $\mathrm{R} / \mathrm{C}$ ratio dalam usaha penangkapan jaring rampus yang didapatkan sebesar 1,17.

Tabel 4. Analisis Finansial Usaha Penangkapan Jaring Rampus di PPI Cituis.

\begin{tabular}{lr}
\hline \multicolumn{1}{c}{ Uraian } & Rata-rata \\
\hline Modal Investasi (Rp) & \\
a. Kapal & 59.000 .000 \\
b. Alat Tangkap & 24.437 .500 \\
c. Mesin & 24.308 .333 \\
d. Alat Bantu (Net Hauler) & 4.666 .667 \\
Total Modal & 112.412 .500 \\
Biaya Tetap (Rp/Tahun) & \\
a. Penyusutan & 23.913 .750 \\
b. Perawatan & 9.850 .000 \\
Total Biaya Tetap & 33.763 .750 \\
Biaya Tidak Tetap (Rp/Tahun) & \\
a. Biaya Operasional & 106.043 .577 \\
b. Biaya Tenaga Kerja & 43.624 .702 \\
Total Biaya Tidak Tetap & 149.668 .279 \\
Biaya Total (Rp/Tahun) & 183.432 .029 \\
Pendapatan (Rp/Tahun) & 215.105 .333 \\
Keuntungan (Rp/Tahun) & 31.673 .304 \\
Pendapatan ABK (Rp/orang/trip) & 151.475 \\
R/C Ratio & 1,17 \\
BEP Harga (Rp/Kg) & Rp68.208 \\
BEP Produksi (Kg/Tahun) & 2.266 \\
ROI (\%) & $17 \%$ \\
IRR (\%) & $66,61 \%$ \\
NPV (Rp, 10 Tahun) & 3,625 \\
Payback Periods (Tahun) & \\
\hline
\end{tabular}


Hal ini menunjukkan bahwa usaha penangkapan yang dilakukan oleh nelayan jaring rampus dapat dikatakan layak dan menguntungkan dalam jangka waktu kedepan, karena nilai $\mathrm{R} / \mathrm{C}$ ratio $>1$. Menurut Rahim \& Hastuti (2007), $\mathrm{R} / \mathrm{C}$ adalah perbandingan antara penerimaan dan biaya. Analisis ini digunakan untuk mengetahui apakah usaha itu menguntungkan atau tidak dan layak untuk dikembangkan. Jika hasil $\mathrm{R} / \mathrm{C}$ ratio $>1$, usaha menguntungkan, sedangkan jika hasil $\mathrm{R} / \mathrm{C}$ ratio $=1$, usaha tersebut dikatakan impas dan apabila hasil $\mathrm{R} / \mathrm{C}$ ratio $<1$, usaha mengalami kerugian.

Nilai BEP harga pada usaha jaring rampus sebesar Rp68.208,-. Sedangkan BEP produksinya sebesar $2.266 \mathrm{~kg}$. Rata-rata jumlah produksi dalam satu tahun adalah $2.677 \mathrm{~kg}$, sementara nilai BEP produksi sebesar $2.266 \mathrm{~kg}$, jumlah produksi > BEP produksi, ini berarti usaha jaring rampus layak untuk dilanjutkan. Berdasarkan Tabel 4 dapat disimpulkan bahwa rata-rata harga yang dapat ditawarkan untuk penjualan hasil tangkapan dari jaring rampus adalah sebesar Rp68.208,-. Sementara rata-rata harga jual yang telah ditetapkan untuk ikan kembung, ikan layur dan ikan pepetek adalah Rp 80.333 > BEP harga, maka usaha usaha jaring rampus layak untuk dilanjutkan.

Nilai ROI dari usaha penangkapan jaring rampus sebesar $17 \%$, sementara nilai suku bunga Bank yang telah ditentukan sebesar $12 \%$. Hal ini menunjukkan bahwa usaha jaring rampus di PPI Cituis dalam kondisi yang menguntungkan karena berdasarkan kriteria ROI bahwa jika Nilai $\mathrm{ROI}>$ dari suku bunga yang berlaku, maka usaha layak dilanjutkan.

Nilai NPV pada usaha penangkapan jaring rampus sebesar Rp214.941.351,-, hal tersebut menunjukkan bahwa pada akhir proyek usaha penangkapan jaring rampus menghasilkan keuntungan. Nilai NPV pada usaha penangkapan jaring rampus bernilai $>0$, menunjukkan bahwa usaha penangkapan jaring rampus ini layak untuk dilanjutkan. Suatu usaha dikatakan semakin baik apabila memiliki nilai NPV yang besar.

Nilai IRR yang didapatkan pada usaha penangkapan jaring rampus sebesar $66,61 \%$. Nilai IRR usaha jaring rampus lebih besar dari discount factor yaitu $12 \%$, yang menunjukan bahwa usaha penangkapan jaring rampus dapat dikatakan layak dilanjutkan untuk kedepannya. Hal ini diperkuat oleh Gunawan, Ismail \& Jayanto (2016), yang menyatakan bahwa, suatu investasi dapat dikatakan layak apabila IRR lebih besar dari nilai interest rate yang ditentukan, semakin tinggi nilai IRR maka investasi akan semakin layak (feasible).

Payback Periods pada usaha penangkapan jaring rampus di PPI Cituis menunjukkan bahwa waktu pengembalian investasi rata-rata adalah 3,625 yaitu 3 tahun 6 bulan 25 hari. Hal ini menunjukkan bahwa tingkat pengembalian modal pada usaha penangkapan jaring rampus di PPI Cituis termasuk dalam kategori sedang karena nilai $\mathrm{PP}<5$ tahun. Hal ini diperkuat oleh Tampubolon, Murni, Ahmad \& Nurmatias (2011) dalam Gunawan et al. (2016), yang menyatakan bahwa, Semakin besar nilai PP maka semakin lama pengembalian modalnya, dan semakin kecil nilai PP, maka semakin cepat pengembalian modal dari usaha tersebut.

\section{PENUTUP}

Analisis teknis jaring rampus yang diperoleh yaitu nilai hanging ratio sebesar 0,6 ; shortening sebesar 0,4; tinggi jaring sebesar 3,672 $\mathrm{m}$ dan luas jaring sebesar $144,7 \mathrm{~m}^{2}$ dalam satu pis.

Tabel 5. Analisis Sensitivitas Usaha Penangkapan Jaring Rampus di PPI Cituis.

\begin{tabular}{llcccc}
\hline $\begin{array}{c}\text { Sekenario } \\
\text { Sensitivitas }\end{array}$ & $\begin{array}{l}\text { Perubahan yang } \\
\text { Berpengaruh }\end{array}$ & $\begin{array}{c}\text { Sebelum } \\
\text { Perubahan }\end{array}$ & $\begin{array}{c}\text { Setelah } \\
\text { Perubahan }\end{array}$ & $\begin{array}{c}\text { Laju } \\
\text { Kepekaan }\end{array}$ & Keterangan \\
\hline Penurunan & NPV (Rp) & 214.941 .351 & 188.938 .839 & 0,80 & Tidak Sensitif \\
Produksi Ikan & IRR $(\%)$ & $66,61 \%$ & $52,51 \%$ & 1,47 & Sensitif \\
$15 \%$ & PP (Tahun) & 4,74 & 5,19 & $-0,56$ & Tidak Sensitif \\
\hline Kenaikan Biaya & NPV (Rp) & 214.941 .351 & 209.861 .071 & 0,35 & Tidak Sensitif \\
Operasional 5\% & IRR (\%) & $66,61 \%$ & $59,14 \%$ & 1,72 & Sensitif \\
& PP (Tahun) & 4,74 & 5,18 & $-1,27$ & Tidak Sensitif \\
\hline Penurunan & NPV (Rp) & 214.941 .351 & 205.469 .163 & 0,54 & Tidak Sensitif \\
Harga Ikan 8\% & IRR (\%) & $66,61 \%$ & $52,53 \%$ & 2,77 & Sensitif \\
& PP (Tahun) & 4,74 & 4,70 & 0,09 & Tidak Sensitif \\
\hline
\end{tabular}


Hasil analisis finansial usaha jaring rampus di PPI Cituis Kabupaten Tangerang menunjukan bahwa usaha tersubut layak untuk dilanjutkan, dengan nilai $R / C$ ratio sebesar 1,17 ; BEP harga sebesar Rp68.208,-; BEP produksi sebesar 2.266 kg; ROI sebesar 17\%; NPV sebesar Rp214.941.351,-; IRR sebesar $66,61 \%$; Payback Periods sebesar 3,625 dan Analisis sensitifitas $<1$.

Hasil penelitian menunjukan bahwa usaha penangkapan jaring rampus dianggap menguntungkan tetapi tidak membuat para nelayan dari usaha penangkapan lain akan berpindah ke usaha penangkapan jaring rampus tersebut. Hasil dari penelitian ini diharapkan dapat menjadi bahan masukan bagi pemerintah daerah dan Lembaga Swadaya Masyarakat (LSM) dalam menentukan langkah-langkah kebijakan untuk pengembangan perikanan tangkap terkhusus unit penangkapan Jaring Rampus di PPI Cituis, Kabupaten Tangerang. Saran yang dapat diberikan adalah perlu diadakan penelitian lebih lanjut mengenai aktivitas dan kapasitas fasilitas terhadap Tempat Pelelangan Ikan di PPI Cituis Kabupaten Tangerang.

\section{UCAPAN TERIMA KASIH}

Penelitian ini tidak lepas dari bantuan berbagai pihak, baik spiritual maupun material, oleh karena itu penulis mengucapkan terima kasih kepada (1) Kedua orang tua penulis (Bapak Didi Mulyadi HS dan Ibu Siti Maemunah); (2) Dr. Abdul Kohar Mudzakir, S.Pi., M.Si. dan Dr. Dian Wijayanto, S.Pi., M.M., M.S.E, selaku Dosen Pembimbing; (3) Kepala Dinas Perikanan dan Kelautan Kabupaten Tangerang dan Kepala Pangkalan Pendaratan Ikan Cituis beserta stafnya; dan semua pihak yang telah memberikan bantuan dan semangat dalam penyelesaian penelitian ini.

\section{DAFTAR PUSTAKA}

Ambarita, D.B., Bathara, L. \& Yulinda, E. (2015). Analisis Usaha Jaring Insang Hanyut (Drift Gill Net) Tambat Labuh Kapal di Pelabuhan Perikanan Nusantara Sibolga Tapanuli Tengah Sumatera Utara. Jurnal Online Mahasiswa FPIK Universitas Riau. Vol 2(2): 1-11. Retrieved from https://www. neliti.com/id/publications.

Aprilyanti, S. (2017). Pengaruh Usia dan Masa Kerja Terhadap Produktivitas Kerja (Studi Kasus: PT. OASIS Water International Cabang Palembang). Jurnal Sinstem dan Manajemen Industri. Vol 1(2): 68-72. doi: 10.30656/jsmi.v1i2.413
Astanu, D.A., Ismono, R.H. \& Rosanti, N. (2013). Analisis Kelayakan Finansial Budidaya Intensif Tanaman Pala di Kecamatan Gisting Kabupaten Tanggamus. Jurnal IImu-IImu Agribisnis. Vol 1(3): 218-225. Doi: 10.23960/jiia.v1i3.218-225.

Brigham, E.F. \& Houston, J.F. (2006). Dasar-Dasar Manajemen Keuangan, alih bahasa Ali Akbar Yulianto, Buku satu, Edisi sepuluh, Indonesia, Jakarta. PT. Salemba Empat.

Damayanti, R., Bambang, A.N. \& Sardiyatmo. (2014). Analisis Harga dan Pemasaran Ikan Kembung Lelaki (Rastrelliger Kanagurta) di Pangkalan Pendaratan Ikan (PPI) Cituis Kabupaten Tangerang. Journal of Fisheries Resources Utilization Management and Technology. Vol 3(3): 176-182.

Dinas Perikanan dan Kelautan Kabupaten Tangerang (2017). Laporan Tahunan Dinas Perikanan dan Kelautan Kabupaten Tangerang Tahun 2013-2 017.Retrievefromhttps://kkp.go.id/wp content/uploads/2017/07/LAPTA\% 20 KKP\%202016.pdf.

Fitria, M., Affandi M.I. \& Nugraha, A. (2013). Analisis Finansial dan Sensitivitas Agroindustri Emping Melinjo Skala Usaha Mikro Kecil dan Menengah (UMKM). Journal of Agribusiness Science. Vol 1(2): 174-180. Doi: 10.23960/jiia.v1i2.\%25p.

Gunawan, A.A., Ismail \& Jayanto, B.B. (2016). Analisis Finansial Usaha Perikanan Jaring Klitik (Gill Net Dasar) dan Jaring Nilon (Gill Net Permukaan) di Pangkalan Pendaratan Ikan (PPI) Tanjungsari Kabupaten Pemalang, Jawa Tengah. Journal of Fisheries Resources Utilization Management and Technology. Vol 5(2): 48-54. Retrieve from https://ejournal3.undip.ac.id/index.php/jfrumt/ article/view/11823/11478.

Keputusan Gubernur Banten Nomor 561/KEP. 318-Huk/2018 Tentang Penetapan Upah Minimum Kabupaten/Kota di Provinsi Banten Tahun 2019.

Pangabean, M. 2017. Studi Deskriptif Tidak Tercapainya Bonus Demografi di Kabupaten Landak Studi Deskriptif Tidak Tercapainya Bonus Demografi di Kabupaten Landak. Jurnal Ekonomi, Bisnis dan Kewirausahaan. Vol 6(1): 43-58. Retrieve from http://jurnal.untan.ac.id/index.php/JJ/article/ view/20725/16879.

Prado, J. (2012). Petunjuk Praktis Bagi Nelayan. Balai Besar Pengembangan Penangkapan Ikan. Indonesia, Jakarta: Balai Besar Penangkapan Ikan.

Rahim, A \& Hastuti R.R.D. (2007). Ekonomika Pertanian, Pengantar Teori dan Kasus. Indonesia, Jakarta. Penebar Swadaya. 
Setiawati, B., Wijayanto, D. \& Pramonowibowo. (2015). Analisis Faktor Produksi Hasil Tangkapan Ikan Kembung (Rastrelliger Sp) pada Alat Tangkap Drift Gill Net di Kab. Ketapang, Kalimantan Barat. Journal of Fisheries Resources Utilization Management and Technology. Vol 4(2): 40-48. Retrieved from https://ejournal3.undip.ac.id/ index.php/jfrumt/article/view/8568/8332.

Sugiyono. (2012). Metode Penelitian Kuantitatif Kualitatif dan RAT. Indonesia, Bandung. Alfabeta.

Suparmoko, M. (2003). Keuangan Negara dalam Teori dan Praktik, (Eds.5). Indoensia, Yogyakarta. BPFE.

Tampubolon., Murni, D., Ahmad, M. \& Nurmatias. (2011). Analisis Finansial Usaha Perikanan yang Beda Pemasarannya. Jurnal Perikanan dan Kelautan. Vol 16 (1): 79-89. Retraived from https://ejournal. unri.ac.id/index.php/JPK/article/view/50/45.

Yunita, I. 2017. Analisis Kelayakan Usaha Dodol Pulut Di Desa Paloh Kecamatan Peusangan Kabupaten Bireuen. Jurnal S. Pertanian. Vol 1(10): 826-836. 